\title{
POLA PEMANFAATAN TUMBUHAN BERKHASIAT OBAT OLEH MASYARAKAT DI SEKITAR KAWASAN HUTAN TAMAN WISATA ALAM KOTA SORONG
}

\author{
FAJRIANTO SAENI \\ FAKULTAS PERTANIAN PROGRAM STUDI KEHUTANAN \\ UNIVERSITAS MUHAMMADIYAH SORONG
}

\begin{abstract}
ABSTRAK
Penelitian bertujuan untuk mengetahui mengidentifikasi dan mengetahui pola pemanfaatan tumbuhan berkhasiat obat oleh masyarakat disekitar kawasan hutan Taman Wisata Alam Kota Sorong. Jenis-jenis tumbuhan berkhasiat obat yang dimanfaatkan oleh masyarakat disekitar hutan Taman Wisata Alam Sorong ditemukan sebanyak 17 (tujuh belas) jenis yang terdiri dari 15 Famili. Pola Pemanfaatan tumbuhan berkhasiat obat oleh masyarakat sekitar hutan Taman Wisata Alam Sorong masih terbatas pada tingkat komponen ekosistem, dimana pemanfaatannya hanya terbatas pada skala konvensional (Conventional uses). Pemanfaatan bagian dari tumbuhan berkhasiat obat oleh masyarakat disekitar hutan Taman Wisata Alam Sorong meliputi buah, daun, kulit dan akar serta ada juga seluruh bagian herba tumbuhan tersebut, dimana proses pemanfaatanya bagian tumbuhan tersebut ada yang segar (basah) ada juga yang kering, ada yang murni dan ada juga yang mencampuri dengan jenis lain.

Kata Kunci: tumbuhan obat, identifikasi, khasiat obat, taman wisata alam,
\end{abstract}

\section{PENDAHULUAN}

Indonesia terdapat banyak potensi tumbuhan yang berkhasiat obat yang sangat potensial untuk menyembuhkan berbagai penyakit yang saat ini belum ada obatnya. Kecenderungan perubahan pola hidup kembali ke alam (back to nature) dikalangan masyarakat internasionalpun kian diminati. Selain itu disadari bahwa, selama ini keberadaan tumbuhan obat banyak menjadi tumpuan hidup masyarakat di sekitar hutan, sehingga harus diakui keberadaannya mempunyai peranan yang strategis untuk dikembangkan pemanfaatannya dalam menunjang upayaupaya peningkatan kesejahteraan dan kesehatan masyarakat.

Menurut Ong (2000), sudah sejak lama bangsa Indonesia mengenal khasiat berbagai ragam jenis tumbuhan sebagai sarana perawatan kesehatan, pengobatan serta untuk memperbaiki diri yang selama ini dikenal sebagai jamu. Dikalangan internasional, jamu dikenal dengan istilah Herbs yang berasal dari bahasa latin Herba yang berarti rumput, tangkai, tangkai hijau yang lunak dan kecil dan agak berdaun.

Di Indonesia, dikenal lebih dari 20.000 jenis tumbuhan obat. Namun, baru
1.000 jenis tanaman telah terdata dan baru 300 jenis yang sudah dimanfaatkan untuk pengobatan tradisional (Hariana, 2006)

Penggunaan tumbuhan di Indonesia sebenarnya sudah dimulai dari zaman nenek moyang. Namun, penggunaannya di tengah masyarakat dimulai saat zaman penjajahan Belanda. Pengenalan dan penggunaan tumbuhan obat dimulai dengan jasa $\mathrm{Ny}$. J. Kloppenburg-Versteegh yang menginventarisasi cara-cara pengobatan tradisional Indonesia. Usaha tersebut oleh pakar-pakar lainnya serta Departemen Kesehatan Republik Indonesia (Hariana, 2006)

Dengan keanekaragaman tumbuhan berkhasiat obat yang ada, terdapat beberapa tumbuhan yang mempunyai nama sama walaupun jenisnya berbeda. Hal tersebut dikarenakan beberapa tumbuhan belum teridentifikasi secara lengkap dan belum banyak ragam yang diketahui masyarakat. Oleh sebab itu, perlu diperkenalkan jenisjenis tumbuhan berkhasiat obat berikut pola pemanfaatannya oleh masyarakat secara umum sebagai bagian dari sistem pengobatan yang murah dan aman. Selain itu, tumbuhan berkhasiat obat juga merupakan potensi kekayaan yang perlu 
dilindungi dan diperkenalkan karena dapat dimanfaatkan sebagai pendukung perekonomian masyarakat secara luas. (Hariana, 2006).

Kawasan hutan Taman Wisata Alam Kota Sorong memiliki berbagai jenis tumbuhan, tentunya ada yang berkhasiat obat dan sangat perlu untuk dilestarikan, oleh sebab itu informasi mengenai sumberdaya alam tersebut sangat diperlukan bagi masyarakat sekitar hutan khususnya dan masyarakat secara luas. Penelitian ini bertujuan untuk mengidentifikasi dan mengetahui pola pemanfaatan tumbuhan berkhasiat obat oleh masyarakat disekitar kawasan hutan Taman Wisata Alam Kota Sorong.

\section{METODOLOGI PENELITIAN \\ Waktu dan Tempat}

Penelitian dilaksanakan dari Bulan Juni Juli 2011. Lokasi penelitian pada areal hutan dan masyarakat di sekitar hutan Taman Wisata Alam Kota Sorong.

\section{B. Bahan dan Alat}

Obyek penelitian ini adalah semua tumbuhan yang berkhasiat obat dimanfaatkan oleh masyarakat disekitar areal hutan Taman Wisata Alam Kota Sorong. Alat yang digunakan dalam penelitian ini adalah kamera, tally sheet, alat tulis menulis dan buku identifikasi tumbuhan obat.

\section{Metode Penelitian}

Metode yang digunakan adalah metode deskriptif dengan teknik observasi lapangan. Deskripsi dan penggambaran pola pemanfaatan tumbuhan obat oleh masyarakat yang hidup disekitar areal Hutan Taman Wisata Alam Sorong, pendekatannya dilakukan dengan wawancara semi struktural (suatu metode pengambilan data dan wawancara dengan daftar pertanyaan/quisioner/angket yang sifatnya tidak terikat pada jawaban tertentu). Data yang dikumpulkan adalah jenis, khasiat/macam penggunaan, bagian yang dimanfaatkan dan pola pemanfaatan tumbuhan berkhasiat obat.

\section{Pelaksanaan Penelitian}

1. Perencanaan penelitian oleh peneliti atas arahan dari dosen pembimbing menyangkut hal teknis dan non teknis terkait dengan jalannya proses penelitian di lapangan.

2. Penyiapan alat dan bahan praktikum meliputi; kamera, tally sheet, alat tulis menulis dan buku identifikasi tumbuhan obat.

3. Penyiapan daftar pertanyaan (Quisioner) sesuai dengan metode penelitian.

4. Dengan menggunakan quisioner pada point 3, peneliti mengadakan pendekatan terhadap masyarakat melalui sistem wawancara bebas tanpa ada pembatasan-pembatasan tertentu dengan pengisian langsung quisioner-quisioner tersebut.

5. Semua data primer yang diperoleh dari point 4 akan dicatat pada buku lapangan (tally sheet) yang meliputi; nama jenis, khasiat/macam penggunaan, bagian yang dimanfaatkan dan pola pemanfaatan tumbuhan berkhasiat obat.

\section{E. Analisis Data}

Data tumbuhan obat yang diperoleh melalui wawancara dari masyarakat disekitar hutan TWA Sorong akan dikumpulkan, kemudian ditabulasi (tabel 1) berdasarkan nama ilmiah dan famili, dianalisis secara deskriptif kualitatif sesuai dengan pola pemanfaatannya (khasiat pemanfaatan, bagian yang dimanfaatkan dan cara pemakaian) serta disajikan dalam bentuk gambar.

\section{HASIL DAN PEMBAHASAN}

\section{A. Jenis-Jenis Tumbuhan yang Berkhasiat Obat Pada Kawasan Hutan Taman Wisata Alam Sorong}

Berdasarkan hasil wawancara dengan masyarakat sekitar yang berdomisili disekitar kawasan Taman Wisata Alam Sorong dan pengamatan dilapangan terlihat bahwa jenis-jenis tumbuhan berkhasiat obat ditemukan sebanyak 17 (tujuh belas) jenis yang terdiri dari 15 Famili yang dapat dilihat pada tabel berikut ini. 
Tabel 1. Jenis-jenis Tumbuhan Berkhasiat Obat Pada Hutan Taman Wisata Alam Sorong Berdasarkan Nama Lokal, Botani dan Famili.

\begin{tabular}{|c|c|c|c|}
\hline No. & Nama Lokal & Nama Botani & Nama Famili \\
\hline 1. & Alang-alang & Imperata cylindrica $L$. & Graminae \\
\hline 2. & Brotowali & Tinospora crispa L. Merr) & Manispermaceae \\
\hline 3. & Daun sirih & Piper betle $L$. & Piperaceae \\
\hline 4. & Kapulaga & Aтотит cardamoтип Will. & Zingiberaceae \\
\hline 5. & Kumis kucing & Orthosiphon spicatus B.B.s & Labiaceae \\
\hline 6. & Mengkudu & Morinda citrifolia $L$. & Rubiaceae \\
\hline 7. & Pecut kuda & Stachytarpheta jamaicensis & Verbenaceae \\
\hline 8. & Patikan kebo & Euphorbia hirta $L$. & Euphprbiaceae \\
\hline 9. & Sambiloto & Andrographis paniculata Burm. & Acanthaceae \\
\hline 10. & Ketepeng cina & Cassia aluta $L$. & Caesalpiniaceae \\
\hline 11. & Pulai & Alstonia scholaris R. Br. & Apoecynaceae \\
\hline 12. & Kayu Gayang & 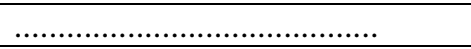 & 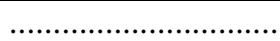 \\
\hline 13. & Kayu Matoa & Pometia pinnata & Sapindaceae \\
\hline 14. & Pinang & Areca catechu $\mathrm{L}$ & Arecaceae \\
\hline 15. & Paku simpai & Cibotium barometz $L$. & 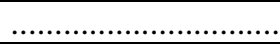 \\
\hline 16. & Kunyit & Curcuma longa & Zingiberaceae \\
\hline 17. & Meniran & Phylanthus urinaria Linn. & Euphorbiaceae \\
\hline
\end{tabular}

Sumber : Data Penelitian, 2008

Tabel 2. Jenis-jenis Tumbuhan Berkhasiat Obat Pada Hutan Taman Wisata Alam Sorong Berdasarkan Jenis, Bagian yang Dimanfaatkan dan Indikasi Khasiat.

\begin{tabular}{|c|c|c|c|}
\hline No. & Spesies Tumbuhan & $\begin{array}{l}\text { Bagian Yang } \\
\text { Dimanfaatkan }\end{array}$ & $\begin{array}{l}\text { Indikasi } \\
\text { Khasiat }\end{array}$ \\
\hline 1. & $\begin{array}{l}\text { Alang-alang (Imperata } \\
\text { cylindrica } L) \text {. }\end{array}$ & Akar (rimpang) & $\begin{array}{l}\text { pengobatan tekanan darah tinggi, } \\
\text { pendarahan akibat panasnya darah seperti } \\
\text { mimisan dan muntah darah }\end{array}$ \\
\hline 2. & $\begin{array}{l}\text { Brotowali (Tinospora } \\
\text { crispa L. Merr) }\end{array}$ & Daun dan Batang & obat luka, deman dan kudis \\
\hline 3. & Daun sirih (Piper betle L.) & Daun & obat keputihan, sifilis, sakit gigi dan bisul \\
\hline 4. & $\begin{array}{l}\text { Kapulaga (Amomum } \\
\text { cardamomun Will.) }\end{array}$ & umbi akar & batuk dan lemah badan \\
\hline 5. & $\begin{array}{l}\text { Kumis kucing (Orthosiphon } \\
\text { spicatus B.B.s) }\end{array}$ & $\begin{array}{l}\text { Seluruh bagian } \\
\text { herba tumbuhan }\end{array}$ & $\begin{array}{l}\text { menghilangkan panas dan lembab serta } \\
\text { masuk angin, infeksi kandung kemih (batu } \\
\text { dalam kandung kemih). }\end{array}$ \\
\hline 6. & $\begin{array}{l}\text { Mengkudu ( Morinda } \\
\text { citrifolia L.) }\end{array}$ & Buah & tekanan darah tinggi, membersihkan darah \\
\hline 7. & $\begin{array}{l}\text { Pecut kuda (Stachytarpheta } \\
\text { jamaicensis) }\end{array}$ & Daun & luka memar dan bisul \\
\hline 8. & $\begin{array}{l}\text { Patikan kebo (Euphorbia } \\
\text { hirta L.) }\end{array}$ & $\begin{array}{l}\text { Seluruh bagian } \\
\text { herba tumbuhan }\end{array}$ & asma, melancarkan kencing, eksim \\
\hline 9. & $\begin{array}{l}\text { Sambiloto (Andrographis } \\
\text { paniculata Burm.) }\end{array}$ & $\begin{array}{l}\text { Seluruh bagian } \\
\text { herba tumbuhan }\end{array}$ & $\begin{array}{l}\text { demam, Influenza, Sakit kepala; batuk } \\
\text { rejan, Kencing manis }\end{array}$ \\
\hline 10. & $\begin{array}{l}\text { Ketepeng cina (Cassia aluta } \\
L \text {. }\end{array}$ & Daun & panu, kurap, dan eksim serta sariawan \\
\hline 11. & Pulai (Alstonia scolaris) & Kulit batang & $\begin{array}{l}\text { demam dan malaria, wanita setelah } \\
\text { melahirkan }\end{array}$ \\
\hline 12. & Kayu Gayang & Kulit batang & penyakit manis (kencing manis) \\
\hline 13. & $\begin{array}{l}\text { Kayu Matoa (Pometia } \\
\text { pinnata) }\end{array}$ & Kulit batang & $\begin{array}{l}\text { pengobatan bagi wanita setelah } \\
\text { melahirkan }\end{array}$ \\
\hline 14. & Pinang (Areca catechu $\mathrm{L})$ & Biji & $\begin{array}{l}\text { cacingan, luka, kudis, membersihkan dan } \\
\text { memperkuat gigi dan gusi }\end{array}$ \\
\hline
\end{tabular}


Lanjutan tabel...

\begin{tabular}{|c|l|c|l|}
\hline 15. & $\begin{array}{l}\text { Paku simpai (Cibotium } \\
\text { barometz L) }\end{array}$ & $\begin{array}{c}\text { Rambut-rambut } \\
\text { yang melapisi } \\
\text { paku simpai }\end{array}$ & pendarahan pada bisul dan luka. \\
\hline 16. & Kunyit (Curcuma longa L.) & Rimpang akar & $\begin{array}{l}\text { demam, Dispepsia (perut kembung, nyeri, } \\
\text { mual, tidak nafsu makan), sakit kuning, } \\
\text { memperlancar ASI }\end{array}$ \\
\hline 17. & $\begin{array}{l}\text { Meniran (Phylanthus } \\
\text { urinaria Linn.) }\end{array}$ & $\begin{array}{l}\text { Seluruh bagian } \\
\text { herba tumbuhan }\end{array}$ & $\begin{array}{l}\text { digigit anjing gila, kencing batu, dan } \\
\text { kencing nanah, demam dan mencret. }\end{array}$ \\
\hline
\end{tabular}

Sumber : Data Penelitian, 2008

\section{B. Deskripsi Kajian Pola Pemanfaatan Jenis-jenis Tumbuhan Berkhasiat Obat Oleh Masyarakat Disekitar Hutan Taman Wisata Alam Sorong}

Deskripsi kajian pola pemanfaatan jenisjenis tumbuhan berkhasiat obat oleh masyarakat disekitar hutan Taman Wisata Alam Sorong berdasarkan jenis dan bagian yang dimanfaatkan serta cara pemakaian (pola pemanfaatan) adalah sebagai berikut :

\section{Alang-alang (Imperata cylindrica $\mathbf{L}$.)}

a. Khasiat : pengobatan tekanan darah tinggi, pendarahan akibat panasnya darah seperti mimisan dan muntah darah.

b. Bagian yang digunakan : akar (rimpang)

c. Cara pemakaian (Pola pemanfaatan) :

- Tekanan darah tinggi ; Akar alangalang yang sudah kering direbus dengan tiga gelas air hingga tersisa satu gelas, kemudian dibagi untuk dua kali minum.

- Pendarahan akibat panasnya darah seperti mimisan dan muntah darah ; akar alang-alang segar dipotongpotong kemudian direbus dengan tiga gelas air hingga tersisa 1 gelas air, kemudian diminum sehari tiga kali.

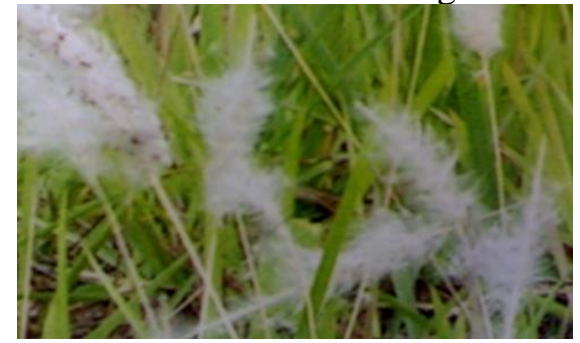

2. Brotowali (Tinospora crispa L. Merr)

a. Khasiat : obat luka, deman dan kudis.

b. Bagian yang digunakan : Daun dan Batang

c. Cara pemakaian (Pola pemanfaatan) :
- Luka ; daun brotowali ditumbuk halus. Bubuhkan pada luka. Ganti 2 kali sehari.

- Demam ; 2 jari batang brotowali direbus dengan 2 gelas air, sampai menjadi 1 gelas. Setelah dingin tambahkan madu secukupnya lalu diminum.

- Kudis ; daun brotowali ditumbuk halus. Bubuhkan pada luka. Ganti 2 kali sehari.

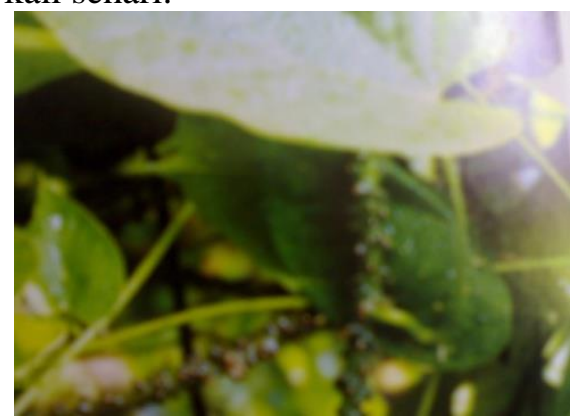

\section{Sirih (Piper betle L.)}

a. Khasiat : obat keputihan, sifilis, sakit gigi dan bisul

b. Bagian yang digunakan : daun

c. Cara pemakaian (Pola pemanfaatan) :

- Keputihan ; 7 - 10 lembar daun sirih direbus dengan 2.5 liter air sampai mendidih, kemudian air rebusan yang sudah hangat langsung dipakai untuk mencuci kemaluan.

- Sifilis; 30 lembar daun siri bersama tangkainya, gula aren dan garam dapur direbus bersama 2 liter air sampai mendidih, kemudian disaring. Minum 3 x sehari secara kontinue.

- Sakit gigi; 3 lembar daun siri direbus dengan 2 gelas air sampai mendidih, setelah dingin dipakai untuk kumur.

- Bisul; cuci daun siri secukupnya, lalu giling sampai halus, usapkan/oleskan 
pada bisul dan sekelilingnya, lalu balut. Ganti 2 kali sehari.

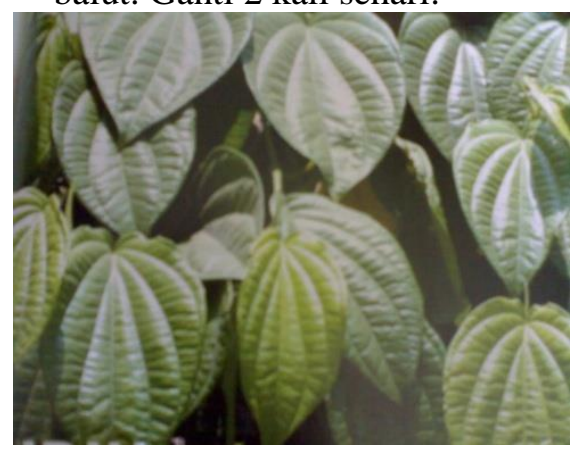

\section{Kapulaga (Amomum cardamomun} Will.)

a. Khasiat :batuk dan lemah badan.

b. Bagian yang digunakan : umbi akar

c. Cara pemakaian (Pola pemanfaatan) :

- Batuk; cuci buah kapulaga sampai bersih, lalu rebus dalam air selama 15 menit. Dinginkan, lalu minum secara kontinue.

- Lemah badan; cuci kapulaga, alangalang dan $1-2$ batang benalu sampai bersih. Rebus semua bahan tersebut dengan 2 gelas air hingga tersisa 1 gelas, dinginkan, disaring lalu diminum $2 \times$ sehari masing-masing setengah gelas.

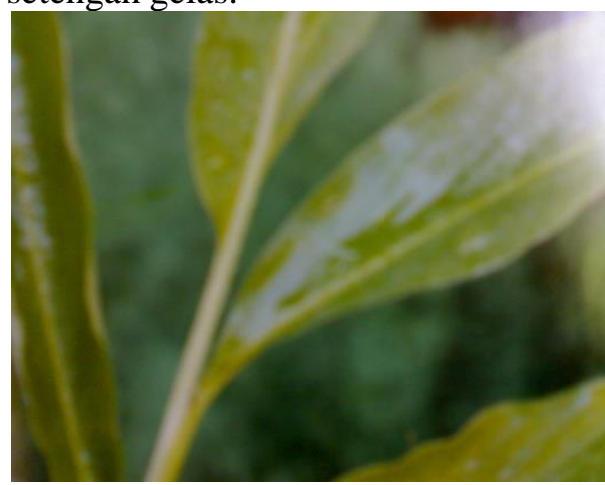

\section{Kunyit (Curcuma longa Linn.)}

a. Khasiat : Demam, Dispepsia (perut kembung, nyeri, mual, tidak nafsu makan), sakit kuning, memperlancar ASI

b. Bagian yang digunakan : Rimpang

c. Cara pemakaian (Pola pemanfaatan) :

- Demam ; cuci rimpang kunyit segar, lalu parut. Aduk parutan kunyit dengan air matang, lalu peras dengan sepotong kain. Minum air perasannya 2 kali sehari.
- Dispepsia (perut kembung, nyeri, mual dan tidak nafsu makan) ; rebus rimpang kunyit segar yang telah dipotong tipis-tipis, 5 butir kapilaga, 5 butir cengkih, dan jahe dalam air. Saring air rebusan, lalu minum sekaligus saat masih hangat.

- Sakit kuning ; cuci rimpang kunyit, lalu parut. Tambahkan 2 sendok makan air, lalu peras dan saring. Minum tiga kali sehari bersama 1 sendok makan madu.

\section{Kumis kucing (Orthosiphon spicatus} B.B.s)

a. Khasiat : menghilangkan panas dan lembab serta masuk angin, infeksi kandung kemih (batu dalam kandung kemih).

b. Bagian yang digunakan : seluruh bagian herba tumbuhan.

c. Cara pemakaian (Pola pemanfaatan) :

- Menghilangkan panas, lembab dan masuk angin; rebus tumbuhan kumis kucing kering atau tumbuhan kumis kucing basah. Minum air rebusannya seperti minum teh.

- Infeksi kandung kemih (batu dalam kandung kemih); rebus 5 - 10 helai daun kumis kucing dalam setengah gelas air. Minum air rebusan 2 kali sehari.

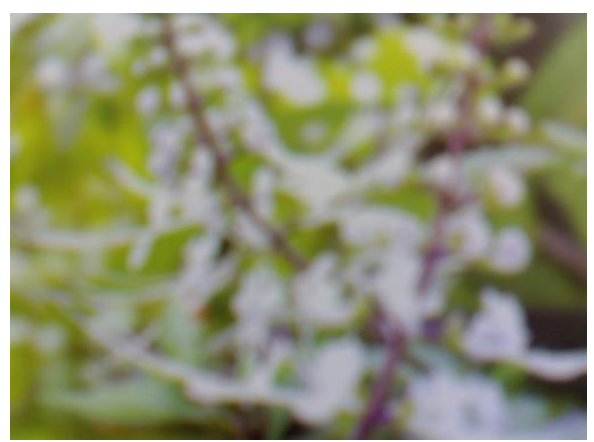

\section{Mengkudu (Morinda citrifolia $L$.)}

a. Khasiat : tekanan darah tinggi, membersihkan darah

b. Bagian yang digunakan : Buah

c. Cara pemakaian (Pola pemanfaatan) :

- Tekanan darah tinggi; cuci bersih 2 buah mengkudu masak, lalu parut. Peras airnya dengan sepotong kain, lalu minum $2-3$ kali sehari secara kontinue. 
- Membersihkan darah; cuci bersih 2 buah mengkudu masak, parut, lalu minum sekaligus $1 \mathrm{x}$ sehari.

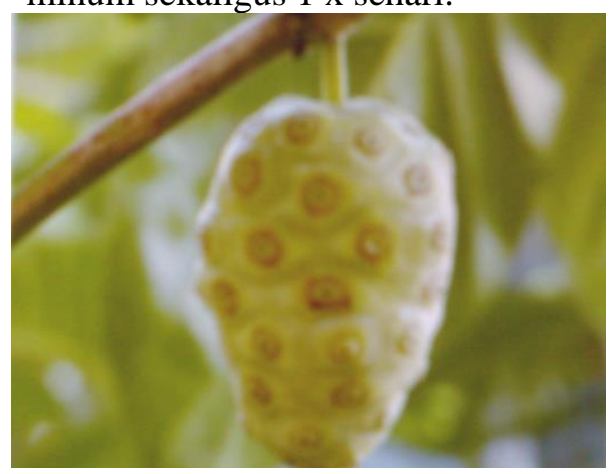

\section{Pecut kuda (Stachytarpheta} jamaicensis)

a. Khasiat : luka memar dan bisul

b. Bagian yang digunakan : daun

c. Cara pemakaian (Pola pemanfaatan) :

- Luka memar dan bisul; tumbuk halus herba pecut kuda segar, lalu tempelkan hasil tumbukan pada bagian tubuh yang sakit.

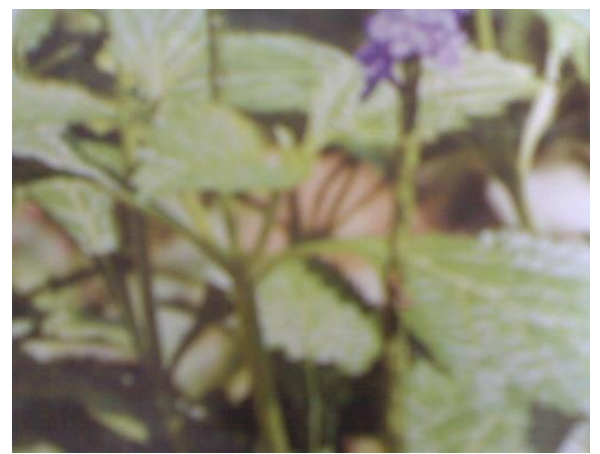

\section{Patikan kebo (Euphorbia hirta L.)}

a. Khasiat : asma, melancarkan kencing, eksim

b. Bagian yang digunakan : seluruh bagian herba tumbuhan

c. Cara pemakaian (Pola pemanfaatan) :

- asma; 1 genggam daun patikan kebo kering, direbus dengan 2-3 gelas air sampai mendidih, kemudian disaring, lalu diminum pagi dan sore.

- Melancarkan kencing ; rebus tumbuhan patikan kebo segar dengan air secukupnya, lalu diminum hasil rebusannya dua kali sehari.

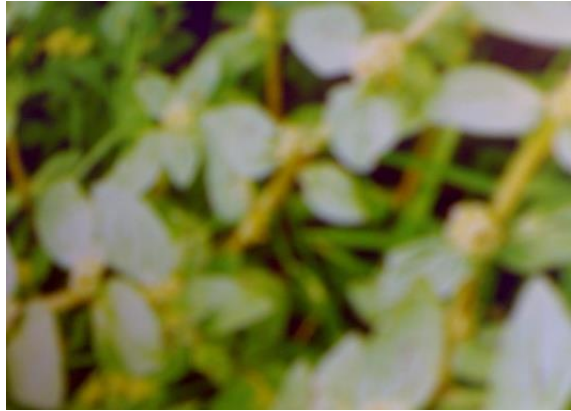

10. Ketepeng cina (Cassia aluta L.)

a. Khasiat : untuk menyembuhkan panu, kurap, dan eksim serta sariawan

b. Bagian yang digunakan : Daun

c. Cara pemakaian (Pola pemanfaatan) :

- Panu, kurap dan eksim ; lumatkan satu genggam daun ketepeng cina segar, lalu tambahkan sedikit tawas (atau 1 sendok makan kapur siri). Gosokkan campuran ini dengan kuat pada kulit yang sakit dua kali sehari.

- Sariawan ; cuci bersih 4 lembar daun ketepeng cina, lalu kunyah dengan garam secukupnya (seperti mengunyah siri) selama beberapa menit. Air daun ketepeng cina ditelan, sedangkan ampasnya dibuang.

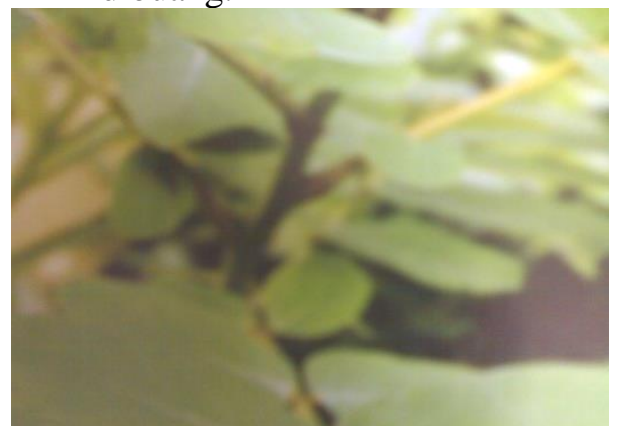

11. Pulai (Alstonia scolaris R. Br.)

a. Khasiat : Demam dan malaria, wanita setelah melahirkan

b. Bagian yang digunakan : Kulit batang.

c. Cara pemakaian (Pola pemanfaatan) :

- Demam dan malaria ; Cuci kulit batang pulai, lalu rebus dengan 3 gelas air hingga tersisa 2 gelas. Minum air rebusan sekali sehari.

- Wanita setelah melahirkan (untuk membersihkan organ dalam) ; Kulit pulai dibersihkan. Tambahkan sepotong kunyit, sedikit jahe dan separuh buah pala. Rebus dengan 
cuka encer dalam periuk tanah liat (tertutup rapat). Setelah mendidih, diangkat lalu dihangatkan, kemudian diminum.

12. Paku simpai (Cibotium barometz L.)

a. Khasiat : pendarahan pada bisul dan luka.

b. Bagian yang digunakan : rambut-rambut yang melapisi paku simpai.

c. Cara pemakaian (Pola pemanfaatan) :

- Pendarahan pada bisul dan luka; Tumbuk rambut batang paku simpai yang berwarna kuning secukupnya, lalu bubuhkan pada bagian yang sakit. Lakukan sebanyak tiga kali sehari.

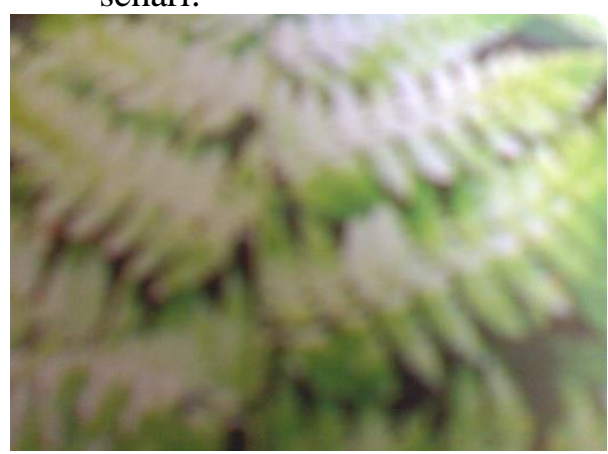

13. Meniran (Phylanthus urinaria Linn.)

a. Khasiat : digigit anjing gila, kencing batu, dan kencing nanah, demam dan mencret.

b. Bagian yang digunakan : seluruh herba tanaman.

- Cacingan ; biji pinang direbus dengan 2 gelas air. Didihkan selama 1 jam, setelah dingin, saring, kemudian minum sekaligus sebelum makan pagi.

- Luka ; biji ditumbuk halus disembur pada luka.

- Kudis ; biji pinang digiling halus, tambahkan sedikit air kapur sirih sampai adonan seperti bubur, dipakai untuk memoles bagian tubuh yang kudisan.

- Membersihkan dan mamperkuat gigi dan gusi ; biji pinang diiris tipis-tipis, kunyah setiap hari selama beberapa menit (ampasnya dibuang).

\section{Kayu gayang}

a. Khasiat : penyakit manis (kencing manis)

b. Bagian yang digunakan : kulit batang c. Cara pemakaian (Pola pemanfaatan) :

- digigit anjing gila ; rebus 4-6 tumbuhan herba maniran (untuk anak kecil gunakan setengahnya) dengan 3 gelas sampai tersisa 1 gelas. Setelah dingin, saring air rebusannya, lalu minum sekaligus satu kali sehari.

- kencing batu, kencing nanah dan demam dan mencret ; cuci bersih herba meniran segar, lalu rebus dengan 3 gelas air hingga tersisa 1 setengah gelas. Minum air rebusan sekali sehari.

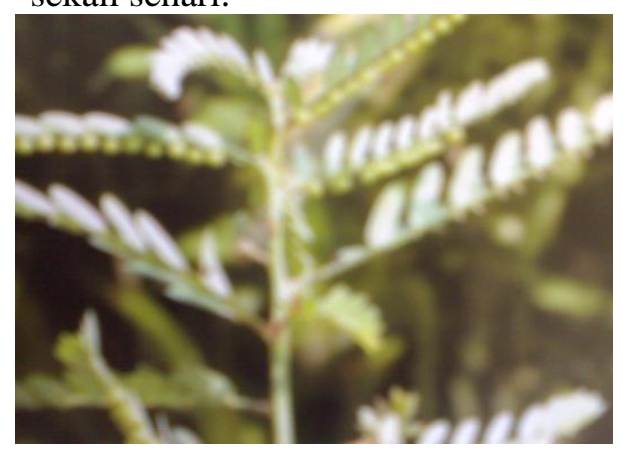

14. Pinang (Areca catechu L.)

a. Khasiat : cacingan, luka, kudis, membersihkan dan memperkuat gigi dan gusi

b. Bagian yang digunakan : Biji

c. Cara pemakaian (Pola pemanfaatan) :

c. Cara pemakaian (pola pemanfaatan) : cuci kulit batang kayu gayang, lalu rebus dengan 3 gelas air hingga tersisa 1 gelas. Minum air rebusan sekali sehari.

16. Kayu matoa (Pometia pinnata)

a. Khasiat : pengobatan bagi wanita setelah melahirkan

b. Bagian yang digunakan : kulit batang

c. Cara pemakaian (Pola pemanfaatan) : cuci kulit batang kayu matoa, lalu rebus dengan 3 gelas air hingga tersisa 1 setengah gelas. Minum air rebusan sekali sehari.

17. Sambiloto (Andrographis paniculata Ness.)

a. Khasiat : Demam, Infulenza, Sakit kepala; batuk rejan, Kencing manis

b. Bagian yang digunakan : seluruh herba tumbuhan 
c. Cara Pemakaian (Pola Pemanfaatan) :

- Demam, Influenza dan sakit kepala ; bubuk kering sambiloto sebanyak 1 gram diseduh dengan 1 cangkir air panas. Setelah dingin, langsung diminum. Lakukan 3-4 kali sehari.

- Batuk rejan ; Daun sambiloto segar diseduh dengan setengah cangkir air panas. Tambahkan madu secukupnya (sambil aduk). Setelah dingin langsung diminum. Dilakukan sehari 3 kali.

- Kencing manis ; Sebanyak 3 tangkai sambiloto utuh dicuci, lalu direbus dengan 4 gelas minum air bersih sampai tersisa 2 gelas. Setelah dingin, disaring. Minum dengan madu seperlunya, 3 kali sehari.

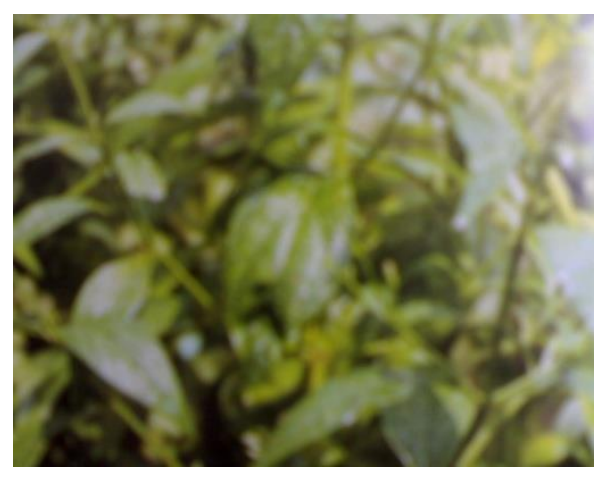

\section{Kesimpulan}

Dengan melihat sedemikian intens dari hasil penelitian dan uraian pembahasan dari skripsi ini, maka secara refresentatif Kehutanan Dirjen Perlindungan Hutan BKSDA Papua II.

Hariana, A., 2006. Tumbuhan Obat dan Khasiatnya Seri 2. Penebar Swadaya. Jakarta.

Ong, C., 2000. Prospek Industri Obat Asli Indonesia. Makalah Seminar dapat ditarik beberapa kesimpulan sebagai berikut :

1. Jenis-jenis tumbuhan berkhasiat obat yang dimanfaatkan oleh masyarakat disekitar hutan Taman Wisata Alam Sorong ditemukan sebanyak 17 (tujuh belas) jenis yang terdiri dari 15 Famili.

2. Pola Pemanfaatan tumbuhan berkhasiat obat oleh masyarakat sekitar hutan Taman Wisata Alam Sorong masih terbatas pada tingkat komponen ekosistem, dimana pemanfaatannya hanya terbatas pada skala konvensional (Conventional uses).

3. Pemanfaatan bagian dari tumbuhan berkhasiat obat oleh masyarakat disekitar hutan Taman Wisata Alam Sorong meliputi buah, daun, kulit dan akar serta ada juga seluruh bagian herba tumbuhan tersebut, dimana proses pemanfaatanya bagian tumbuhan tersebut ada yang segar (basah) ada juga yang kering, ada yang murni dan ada juga yang mencampuri dengan jenis lain.

\section{DAFTAR PUSTAKA}

Anonim, 1985. laporan Survey Identifikasi Pengembangan Hutan Taman Wisata Sorong. Departemen

Tumbuhan Obat di Indonesia". Kerjasama Indoneisa Resources Centre for Indigenous (INRIK), Universitas Pajajaran dan Yayasan Ciungwanara dengan Yayasan 